\title{
Screening for Candidate Hepatic Growth Factors by Selective Portal Infusion after Canine Eck's Fistula
}

\author{
Antonio Francavilla ${ }^{2}$, Thomas E. Starzl ${ }^{1}$, Ken Porter ${ }^{1}$, Carlo Scotti Foglieni ${ }^{1}$, George K. \\ Michalopoulos $^{3}$, Giuseppe Carrieri ${ }^{1}$, Jose Trejo ${ }^{1}$, Alessandro Azzarone ${ }^{2}$, Michele Barone ${ }^{2}$, \\ and Qi Hua Zeng ${ }^{1}$ \\ ${ }^{1}$ Department of Surgery, University Health Center of Pittsburgh, Pittsburgh, Pennsylvania 15213 \\ ${ }^{2}$ Department of Gastroenterology, University of Bari, Bari, Italy \\ ${ }^{3}$ Department of Pathology, Duke University School of Medicine, Durham, North Carolina
}

\section{Abstract}

Completely diverting portacaval shunt (Eck's fistula) in dogs causes hepatocyte atrophy, disruption of hepatocyte organelles, fatty infiltration and low-grade hyperplasia. The effect of hepatic growth regulatory substances on these changes was assessed by constantly infusing test substances for four postoperative days after Eck's fistula into the detached left portal vein above the shunt. The directly infused left lobes were compared histopathologically with the untreated right lobes. In what has been called an hepatotrophic effect, stimulatory substances prevented the atrophy and increased hepatocyte mitoses. Of the hormones tested, only insulin was strongly hepatotrophic; $\mathrm{T}_{3}$ had a minor effect, and glucagon, prolactin, angiotensin II, vasopressin, norepinephrine and estradiol were inert. Insulin-like growth factor, hepatic stimulatory substance, transforming growth factor- $\alpha$ and hepatocyte growth factor (also known as hematopoietin A) were powerfully hepatotrophic, but epidermal growth factor had a barely discernible effect. Transforming growth factor $-\beta$ was inhibitory, but tamoxifen, interleukin-1 and interleukin-2 had no effect. The hepatotrophic action of insulin was not altered when the insulin infusate was mixed with transforming growth factor- $\beta$ or tamoxifen. These experiments show the importance of in vivo in addition to in vitro testing of putative growth control factors. They illustrate how Eck's fistula model can be used to screen for such substances and possibly to help delineate their mechanisms of action.

\begin{abstract}
Regulation of liver mass and the control of hepatic regeneration are poorly understood and presumably related processes. Hormones, soluble mediators and other substances that can influence hepatocyte size, proliferation or both have been identified with in vitro or in vivo models of testing (1-10). Both test systems are important because no assurance exists that agents with in vitro activity are physiologically important. Moreover, substances with potent physiological activity in the intact animal may be inert when tested in vitro (11).

An in vivo canine model of portacaval shunt (Eck's fistula) has been used previously to demonstrate striking hepatotrophic qualities of insulin $(3,4)$, crude (12) and partially purified (13) hepatic stimulatory substance (HSS) in the cytosol of regenerating livers and the immunosuppressive drugs cyclosporine (14) and FK 506 (15). In this study, the same technique has been used to test most other growth factors that have been reported to influence hepatocyte proliferation.
\end{abstract}

Copyright (C) 1991, by The American Association

Address reprint requests to: Thomas E. Starzl. M.D., Ph.D., Department of Surgery, 3601 Fifth Avenue, University of Pittsburgh, Pittsburgh, PA 15213.. 


\section{MATERIALS AND METHODS}

\section{Experimental Model}

Conditioned female beagle dogs weighing 8.3 to $13 \mathrm{~kg}$ were anesthetized with intravenous sodium pentobarbital, halothane and nitrous oxide. The experimental model was as described previously $(3,4,12,14,15)$. Side-to-side portacaval shunt was performed and converted to a functional end-to-side shunt by ligation of the portal vein above the anastomosis (Figure 1A). The main right and left portal veins were isolated, and the right vein was ligated. The left portal branch was cannulated with a $2.4 \mathrm{~mm}$ (internal diameter) cannula that was advanced for $1 \mathrm{em}$, secured and led through the abdominal wall to a calibrated and battery-driven constant infusion pump (Cormed II AIF, Cormed Inc., Murray Hill, NJ) that was incorporated into a nonrestricting light body cast. Test substances dissolved in saline modified by the addition of $5 \mathrm{mmol} / \mathrm{L}$ ammonium acetate and $5 \mathrm{mg} / \mathrm{L} \mathrm{BSA}$ (to avoid aggregation on the plastic tubing) were infused continuously at $25 \mathrm{ml} / \mathrm{day}$ for 4 days beginning promptly after completion of the portacaval shunt. Previous experiments established that insulin and glucagon in the doses used, and both together, had no effect on blood sugar (4). In control experiments (data not shown) it was established that the vehicle is inert. The animals were given a sugar water diet $a d$ libitum on the day of the operation and a regular diet thereafter. Before the animals were killed, hepatic and kidney function tests were obtained. Rises in serum creatinine or bilirubin or falls in serum albumin were not seen. Minor increases in ALT and alkaline phosphatase typical of Eck's fistula (16) were common. All dogs were active, ate normally and appeared clinically well.

\section{Pathological End Points}

Four days after portacaval shunt, $0.2 \mathrm{mCi} / \mathrm{kg}$ of intravenous $\left({ }^{3} \mathrm{H}\right)$ thymidine was given with a specific activity of 80 to $90 \mathrm{Ci} / \mathrm{mmol}$ (Dupont New England Nuclear Research Products, Boston, MA). Two hours later, while the dogs were under sodium pentobarbital anesthesia, specimens were taken from left and right lobes of the liver and fixed in 10\% normal buffered formalin. The dogs were killed with an intravenous bolus of potassium chloride. The patency of the anastomosis and the correct position of the catheter tip were confirmed.

The liver tissue was processed and stained with hematoxylin and eosin. Autoradiography was carried out with Kodak NTB2 liquid emulsion (Eastman Kodak, Rochester, NY) with an exposure time of at least 30 days. The number of replicating hepatocytes as an index of hepatocyte regeneration was determined by counting the number of $\left({ }^{3} \mathrm{H}\right)$ thymidine-labeled nuclei per 1,000 hepatocytes. The size of individual hepatocytes (index of hypertrophy or atrophy) was determined by tracing out at least 500 midzonal liver cells projected on standard thickness paper, cutting out the individual silhouettes and weighing each. This method has been shown to be accurate for determining hepatocyte cell size and has been validated by planimetry and studies of unicellular organisms, the size of which has been determined directly (2).

In normal, unaltered dogs, $1.5 \pm 0.5$ (S.D.) labeled hepatocytes per 1,000 hepatocytes are present in the liver, with the size of midzonal hepatocytes being $0.16 \pm 0.01$ (S.D.) size units. After Eck's fistula, the replication rate is nearly tripled, and the hepatocyte size is almost halved within 4 days $(4,12,15)$, after which a stable state exists $(17,18)$. The exceptional reproducibility of these changes makes it easy to determine the effects of drugs on this transformation. Each experiment serves as its own control because the cell replication and size in the directly infused liver lobes can be compared with these measures in the contralateral uninfused lobes. 


\section{Agents Tested}

The doses of insulin and glucagon were the same as those shown in earlier experiments not to cause changes in blood sugar (4). The amount of the other agents was guided by the previously determined effective dose by weight of HSS (13).

Hormones (Table 1)-Included in this group were: insulin (human regular semisynthetic, E.R. Squibb \& Sons Inc., Princeton, NJ); glucagon, prolactin, vasopressin, norepinephrine estradiol and $\mathrm{T}_{3}$, (Sigma Chemical Co., St. Louis, MO); and angiotensin II (Peninsula Laboratories, Belmont, CA).

Growth Factor Stimulators (Table 2)-These items included: HSS produced in our laboratory (11); insulin-like growth factor (IGF-II) (Collaborative Research, Inc., Bedford, MA); epidermal growth factor (EGF) (Collaborative Research, Inc.); transforming growth factor- $\alpha$ (TGF- $\alpha$ ) (Peninsula Laboratories, Inc.); and hepatocyte growth factor (HGF, also called hepatopoietin A or HPTA), which was purified at Duke University, Durham, NC by George Michalopoulos (19).

Growth Factor Inhibitors (Table 3)-These inhibitors included: tamoxifen (Sigma Chemical Co.); TGF- $\beta$, interleukin 1 (IL-1) and interleukin 2 (IL-2) (Collaborative Research, Inc.).

Stimulator-Inhibitor CombinatiollB (Table 4)—In separate experiments, insulin, which was one of the most potent in vivo stimulators when used alone, was mixed with the TGF- $\beta$, which was the only unambiguously inhibitory substance that could be identified. The mixture was infused into the left portal branch at the same time that insulin alone was infused into the right portal branch (Figure 1B). A similar experiment was performed with an insulin-tamoxifen mixture infused in one portal branch vs. insulin alone in the other.

\section{Statistical Analysis}

In each experimental group, the rate of cell renewal as quantitated by the number of labeled nuclei and the size units were compared between the left (infused) liver lobes vs. the right lobes that were not infused except in the bilateral infusion experiments (Figure 1B). Data were reported as mean \pm S.D. The Student's one-tail $t$ test was used to determine the significance of differences. A p value less than 0.05 was considered significant.

\section{RESULTS}

Hormones

Insulin was the only hormone that prevented the hepatocyte atrophy caused by portacaval shunt and provoked a major increase in hepatocyte proliferation (Table 1). The hepatocytes on the insulin-protected side had intact organelles, less fat deposition and a higher concentration of glycogen. Glucagon had no effect. These results were the same as previously reported $(3,4$, 14). At a dose of $100 \mathrm{ng} / \mathrm{kg} / \mathrm{day}, \mathrm{T}_{3}$ caused proliferation to a much smaller degree, but it did not prevent atrophy. Prolactin, angiotensin II, vasopressin, norepinephrine and estradiol were inert at the doses used (Table 1).

\section{Growth Stimulation Factors}

The same dramatic effects caused by insulin were produced by $50 \mathrm{ng} / \mathrm{kg} /$ day doses of IGF-II, TGF, HGF and HSS purified 381,000 times from the cytosol of regenerating rat hepatocytes. EGF had barely demonstrable activity (Table 2), which was not different within a dose range of 50 to $150 \mathrm{ng} / \mathrm{kg} / \mathrm{day}$. 


\section{Growth Inhibitors}

At a dose of $5 \mathrm{ng} / \mathrm{kg} / \mathrm{day}$. TGF- $\beta$ reduced by half the low-grade hyperplasia caused by portacaval shunt and caused further shrinkage of the already atrophic hepatocytes. At the same doses, activity of IL-1 and IL-2 could not be demonstrated. Tamoxifen was without effect.

\section{Stimulator-Inhibitor Combinations}

In the double-infusion experiments shown in Figure 1B, the hepatocyte proliferation and prevention of atrophy mediated by insulin were unaltered by the addition of tamoxifen or by the mixing of insulin with doses of TGF- $\beta$, which by themselves were inhibitory (Table 4 ).

\section{DISCUSSION}

An active test substance prevents the expected acute hepatocyte atrophy and organelle disruption in the infused liver lobes; in addition, the characteristically increased resting hepatocyte mitoses caused by Eck's fistula is doubled or tripled by the most potent additives. These so-called hepatotrophic responses have been described previously for insulin $(3,4)$, crude (12) or purified (13) cytosolic extract from regenerating livers and the immunosuppressive agents cyclosporine (14) and FK 506 (15).

Only a limited number of agents possess these so-called hepatotrophic qualities. The observations herein reported have added IGF-II, TGF- $\alpha$ and HGF in nanogram quantities to the high potency substance list. Numerous others substances that have been reported to be strong stimulators in tissue culture or in some instances in intact animals (e.g., $\left.\mathrm{T}_{3}\right)(1,20)$ had little or no effect. $\mathrm{T}_{3}$ (Table 1) caused low-grade hyperplasia, and EGF that stimulates hepatocytes in culture (21) had barely discernible activity in our model even when double and triple the planned $50 \mathrm{ng} /$ day doses were given (Table 2). Although EGF resembles TGF- $\alpha$ structurally and functionally and has the same cell-surface receptor (22), its inactivity relative to TGF- $\alpha$ was not surprising. TGF- $\alpha$ is a stronger mitogen than EGF for hepatocytes in vitro (23), and in many other functions besides hepatocyte replication it is a stronger affector (24). Other putative stimulators that had little or no effect in Eck's fistula preparation included the hormones prolactin (25), angiotensin II (26), vasopressin (7), norepinephrine (6,27), estradiol (28) and glucagon (29).

In the "priming and progression" concept proposed by Fausto (30), the disparate results with in vitro and in vivo testing could reflect actions at different times in the cell cycle. In Fausto's nomenclature, initiators that activate the $\mathrm{g} 0-\mathrm{g} 1$ transition within a few hours already may be in the liver or blood or else synthesized almost immediately after a regeneration stimulus (30). Ions, nutrients and growth regulators that tested negatively in our experiments could be in this category. Some of the progression phase factors in Fausto's scheme regulate not only g0-1 but also the DNA synthesis and mitosis that follow in g1-S. Most of the powerful stimulators in our Eck's fistula model do not initiate replication in vitro but might best be termed "augmenters," acting solely or m.ainly at the g1-S interphase.

An alternate classification scheme for liver mitogens is based on the actions of compounds on hepatocyte cultures. Complete mitogens in the alternative classification of Michalopoulos (31) are stimulatory in chemically defined in vitro conditions, whereas his term "incomplete mitogen" (comitogen) is reserved for substances such as nonepinephrine, which are not directly mitogenic but enhance the effect of complete mitogens and/or counteract the effect of mitotic inhibitors (32). The comitogenic action of norepinephrine is strongly dependent on the presence of insulin (27), which possibly explains why a norepinephrine effect could not be seen in our Eck's fistula experiments. 
Depriving the liver of direct access to endogenous insulin is the single most important and most easily demonstrable cause for the changes that follow Eck's fistula $(3,4,12)$ or other more complex operations that put the liver in an insulinoprival state (16-18,33-35). The crucial demonstration was that intraportally administered exogenous insulin by itself could prevent most of the changes of Eck's fistula $(3,4)$. However, in hepatocyte cultures, the principal and essential effect of insulin by itself is to maintain viable and healthy hepatocytes but with minimal or no mitogenicity (36-41).

IGF-II was of equal potency to insulin in the Eck's fistula model, although it also has little or no inherent mitogenicity in hepatocyte culture (42). IGF-II has been described in hepatomas in the woodchuck hepatitis model (43), and its role in modulating normal and neoplastic hepatocytes bears investigation. Additionally, strong evidence exists that IGF-I and IGF-II can act not only through their own receptors but also through the insulin receptor in many in vivo and in vitro systems (44). Thus the strong effects of IGF-II in Eck's fistula system herein reported may reflect the well-known insulin mimetic role of this substance. Even the smallest dose used had a full hepatatrophic effect.

The critical value of such in vivo testing is evident from the results herein reported. Of the seven most potent hepatotrophic substances identified so far with Eck's fistula model, only TGF- $\alpha$ (45) and HGF (19) also have had strong mitogenic properties in tissue culture. The demonstration that HGF also had a strong effect in Eck's fistula model is the first evidence of its in vivo potency. HGF is produced in multiple sites, including the exocrine portion of the pancreas (46), and its physiological role remains to be determined. However, using in vitro testing for growth effects, researchers might pass over as unexciting not only insulin and IGFII but also cyclosporine (47), FK 506 (47) and HSS. However, all five are in the first rank of Michalopoulos comitogens.

Aside from the fact that HSS is not stimulatory in hepatocyte culture (10), a comitogenic role of HSS (using the Michalopoulos definition) has been suspected on other grounds. In the experiments herein reported, HSS was purified from the cytosol of regenerating rat livers and found to be potent in dogs, showing that it is not species specific. In dogs, the crude cytosol from the residual liver fragment does not possess stimulatory activity until $48 \mathrm{hr}$, reaching maximum potency after $72 \mathrm{hr}$ as determined in the canine Eck's fistula model (12) or by the augmentation of hepatic regeneration in a second dog after subtotal hepatectomy (48). The time when hepatic regeneration in dogs reaches its peak is 3 days (49).

The list of other potential comitogens that could be studied with Eck's fistula model is long and includes hundreds of xenobiotics such as phenobarbital and peroxisome proliferators (50). Although these agents are not mitogenic in vitro, they stimulate DNA synthesis in the liver in vivo and function as powerful hepatic tumor promoters.

In addition to screening for stimulatory compounds, Eck's fistula model should be valuable for the in vivo screening and study of substances that are inhibitory. Against the background of heightened cell renewal, TGF- $\beta$, a powerful inhibitor of hepatocyte proliferation in vitro (51, 52 ), was shown in our current experiments to inhibit ongoing proliferation in addition to reducing further the size of the already atrophic hepatocytes. The other test substances that were without activity in our Eck's fistula experiments but which have been reported to be inhibitory in tissue culture systems were tamoxifen (28), IL-1 and IL-2 (53).

Finally, the feasibility of using this model to study the interrelation of stimulators and inhibitors was demonstrated. In our experiments the reduction of hepatocyte replication and size by TGF$\beta$ was overridden by insulin when the two agents were given together. It will be important to see the extent to which these interactions are dose related and time related and to test the interactions of growth inhibitors with other stimulatory substances. 


\section{Acknowledgments}

Aided by research grants from thp Veterans Administration and Project Grants No. DK 29961 and CA 35373 from the National Institutes of Health, Bethesda, Maryland.

\section{REFERENCES}

1. Short J, Brown RF, Husakova JR, Gilbertson JR, Zemel R, Lieberman I. Induction of DNA synthesis in the liver of the intact animal. J Bioi Chem 1972;47:1757-1763.

2. Starzl TE, Francavilla A, Halgrimson CG, Porter KA, Brown TH, Putnam CW. The origin, hormonal nature and action of hepatotrophic substance in portal venous blood. Surg Gynecol Obstet 1973;137:179-199. [PubMed: 4353133]

3. Starzl TE, Porter KA, Putnam CW. Intraportal insulin protects from the liver injury of portacaval shunt in dogs. Lancet 1975;2:1241-1246. [PubMed: 53727]

4. Starzl TE, Watanabe K, Porter KA, Putnam CW. Effect of insulin, glucagon, and insulin/glucagon infusion on liver morphology and cell division after complete portacaval shunt in dogs. Lancet 1976;1:821-825. [PubMed: 56646]

5. Bucher, NLR.; McGowan, JA.; Patel, U. Hormonal regulation of liver growth. In: Dirksen, ER.; Prescott, DM.; Fox, CF., editors. Cell reproduction: ICN/UCLA symposium on molecular cell biology. Vol. Vol 12. Academic Press; New York: 1978. p. 661-670.

6. Cruise JL, Houck K, Michalopoulos GK. Induction of DNA synthesis in cultured rat hepatocytes through stimulation of alpha 1 adrenoreceptor by norepinephrine. Science 1985;277:749-751. [PubMed: 2982212]

7. Russell WE, Bucher NLR. Vasopressin modulates liver regeneration in the Brattleboro rat. Am J Physiol 1983;245:G321-G324. [PubMed: 6881353]

8. Leffert HL, Koch KS, Moran T, Rubacalva B. Hormonal control of rat liver regeneration. Gastroenterology 1979;76:1470-1482. [PubMed: 220134]

9. Fausto N, Mead JE. Regulation of liver growth: protooncogenes and transforming growth factors. Lab Invest 1989;60:4-13. [PubMed: 2642989]

10. LaBrecque DR, Pesch LA. Preparation and partial characterization of hepatic regenerative stimulator substance (HSS) from rat liver. J Physiol 1975;248:273-284. [PubMed: 1151784]

11. Francavilla A, Ove P, Polimeno L, Coetzee M, Makowka L, Rose J, Van Thiel DH, et al. Extraction and partial purification of a hepatic stimulatory substance in rats, mice, and dogs. Cancer Res 1987;47:5600-5605. [PubMed: 3664466]

12. Starzl TE, Terblanche J, Porter KA, Jones AF, Usiu S, Mazzoni G. Growth-stimulating factor in regenerating canine liver. Lancet 1979;2:127-130. [PubMed: 84151]

13. Francavilla A, Barone M, Van Thiel DH, Mazzaferro V, Prelich J, Stanl TE. Further steps of HSS (hepatic stimulatory substance) purification. Dig Dis Sci 1991;36:674-680. [PubMed: 2022170]

14. Mazzaferro V, Porter KA, Scotti Foglieni C, Venkataramanan R, Makowka L, Rossaro L, Francavilla A, et al. The hepatotrophic influence of cyclosporine. Surgery 1990;107:533-539. [PubMed: 2185568]

15. Starzl TE, Porter KA, Mazzaferro V, Todo S, Fung J, Francavilla A. Hepatotrophic effects of FK 506 in dogs. Transplantation 1991;51:67-70. [PubMed: 1702912]

16. Starzl TE, Porter KA, Francavilla A. The Eck fistula in animals and humans. Curr Probl Surg 1983;20:688-767.

17. Starzl TE, Lee IY, Porter KA, Putnam CW. The influence of portal blood upon lipid metabolism in normal and diabetic dogs and baboons. Surg Gynecol Obstet 1975;140:381-396. [PubMed: 18689027]

18. Starzl TE, Porter KA, Kashiwagi N, Lee IY, Russell WJI, Putnam CW. The effect of diabetes mellitus on portal blood hepatotrophic factors in dogs. Surg Gynecol Obstet 1975;140:549-562. [PubMed: 18689029]

19. Michalopoulos B, Houck KA, Dolan ML, Lvetteke NC. Control of hepatocyte replication by two serum factors. Cancer Res 1984;44:4414-4419. [PubMed: 6235912] 
20. Francavilla A, Ove P, Van Thiel DH, Coetzee ML, Wu S-K, DiLeo A, Starzl TE. Induction of hepatocyte stimulating activity by $\mathrm{T}_{3}$ and appearance of the activity despite inhibition of DNA synthesis by adriamycin. Horm Metab Res 1984;16:237-242. [PubMed: 6376310]

21. Richman RA, Claus TH, Pilkes SJ, Friedman DL. Hormonal stimulation of DNA synthesis in primary cultures of adult rat hepatocytes. Proc Natl Acad Sci USA 1976;73:3589-3592. [PubMed: 1068471]

22. Marquardt H, Hunkapiller MW, Hood LE, Todaro GJ. Rat transforming growth factor type I: structure and relation to epidermal growth factor. Science 1984;223:1079-1082. [PubMed: 6320373]

23. Brenner DA, Koch KS, Leffert HL. Transforming growth factor-alpha stimulates proto-oncogene cjun expression and a mitogenic program in primary cultures of adult rat hepatocytes. DNA 1989;8:279-285. [PubMed: 2504570]

24. Schreiber AB, Winkler ME, Dervnick R. Transforming growth factor-alpha: A more potent angiogenic mediator than epidermal growth factor. Science 1986;232:1250-1253. [PubMed: 2422759]

25. Buckley AR, Putnam CW, Crowe PD, Shah GN, Bauman PA, Laird HE, Russell DH. Prolactinprovoked activation of membrane and nuclear protein kinase $\mathrm{C}$ following partial hepatectomy. Dig Dis Sci. 1991 in press.

26. Carr BI. Gene expression and mitogenic response of rat hepatocytes to EGF, TGF, alpha, and angiotensinogen gene products. Proc Amer Assoc Can Res 1990;31:1332-1332.

27. Cruise JL, Michalopoulos G. Norepinephrine and epidermal growth factor: dynamics of their interaction in the stimulation of hepatocyte DNA synthesis. J Cell Physiol 1985;125:45-50. [PubMed: 3876347]

28. Francavilla A, Polimeno L, DiLeo A, Barone M, Ove P, Coetzee M, Eagon P, et al. The effect of estrogen and tamoxifen on hepatocyte proliferation in vivo and in vitro. HEPATOLOGY 1989;9:614620. [PubMed: 2784403]

29. Nakamura T, Shinno H, Ichihara A. Insulin and glucagon as a new regulator system for tryptophan oxygenase activity demonstrated in primary cultured rat hepatocytes. J Biol Chem 1980;255:75337535. [PubMed: 6249804]

30. Fausto, N. Liver regeneration. In: Zakim, D.; Boyer, TD., editors. Hepatology: a textbook of liver disease. 2nd ed.. W.B. Saunders Company; Philadelphia: 1990. p. 49-65.

31. Michalopoulos GK. Liver regeneration: molecular mechanisms of growth control. FASEB J 1990;4:176-187. [PubMed: 2404819]

32. Houck K, Michalopoulos GK. Altered responses of regenerating hepatocytes to norepinephrine and transforming growth factor type beta. J Cell Physiol 1989;141:503-509. [PubMed: 2574179]

33. Starzl TE, Porter KA, Kashiwagi N, Putnam CW. Portal hepatotrophic factors, diabetes mellitus, and acute liver atrophy, hypertrophy and regeneration. Surg Gynecol Obstet 1975;141:843-858. [PubMed: 1188560]

34. Starzl TE, Francavilla A, Porter KA, Benichou J, Jones AF. The effect of splanchnic viscera removal upon canine liver regeneration. Surg Gynecol Obstet 1978;147:193-207. [PubMed: 210529]

35. Starzl TE, Francavilla A, Porter KA, Benichou J. The effect upon the liver of evisceration with or without hormone replacement. Surg Gynecol Obstet 1978;146:524-531. [PubMed: 205003]

36. Gerschenson LE, Okigaki T, Anderson M, Molson J, Davidson MB. Fine structural and growth characteristics of cultured rat liver celis: insulin effects. Exp Cell Res 1972;71:49-58. [PubMed: 4554574]

37. Wagle SR, Ingebretsen WR Jr, Sampson L. Studies on the effects of insulin on glycogen synthesis and ultrastructure in isolated rat liver hepatocytes. Biochem Biophys Res Commun 1973;53:937941. [PubMed: 4354454]

38. Michalopoulos GK, Pitot HC. Primary culture of parenchymal liver celis on collagen membranes: morphological and biochemical observations. Exp Cell Res 1975;94:70-78. [PubMed: 243]

39. Junge U, Nagamori S. Effect of insulin and glucagon on the DNA synthesis of hepatocyte cultures. Verh Dtsch Ges Inn Med 1976;82:385-386. [PubMed: 1029217]

40. Bernaert D, Wanson JC, Frochmans P, Popowski A. Effect of insulin on ultrastructure and glycogenesis in primary cultures of adult rat hepatocytes. J Cell Biol 1977;74:818-900.

41. Bucher NLR. Insulin, glucagon, and the liver. Adv Enzyme Regul 1976;15:221-230. [PubMed: 1030184] 
42. Froesch ER, Schmid C, Schwander J, Zapf J. Actions of insulin like growth factors. Annu Rev Physiol 1985;47:443-467. [PubMed: 2986538]

43. FU XX, Su CY, Lee y, Hintz R, Biempica L, Snyder R, Rogler CE. Insulin-like growth factor II expression and oval cell proliferation associated with hepatocarcinogenesis in woodchuck hepatitis virus carriers. J Virol 1988;62:3422-3430. [PubMed: 2457114]

44. Zapf J, Froesch ER. Insulin-like growth factors/somatomedins: structure, secretion, biological actions and physiological role. Horm Res 1986;24:121-130. [PubMed: 3530937]

45. Mead JE, Fausto N. Transforming growth factor alfa may be a physiological regulator of liver regeneration by means of an autocrine mechanism. Proc Natl Acad Sci USA 1989;86:1558-1561. [PubMed: 2922399]

46. Zarnegar R, Muga S, Rahija R, Michalopoulos GK. Tissue distribution of HPTA, a heparin-binding polypeptide growth factor for hepatocytes. Proc Nat Acad Sci USA 1990;87:1252-1256. [PubMed: 2137248]

47. Francavilla A, Barone M, Starzl TE, Zeevi A, Scotti C, Carrieri G, Mazzaferro V, et al. FK 506 as a growth control factor. Transplant Proc 1990;22:90-92. [PubMed: 1689912]

48. Terblanehe J, Porter KA, Starzl TE, Moore J, Patzelt L, Hayashida N. Stimulation of hepatic regeneration after partial hepatectomy by infusion of a cytosol extract from regeneration dog liver. Surg Gynecol Obstet 1980;151:538-544. [PubMed: 6998027]

49. Francavilla A, Porter KA, Benichou J, Jones AF, Starzl TE. Liver regeneration in dogs: morphologic and chemical changes. J Surg Res 1978;25:409-419. [PubMed: 213658]

50. Tsai WH, Cruise JL, Michalopoulos GK. Blockade of alpha-1 adrenergic receptor inhibits hepatic DNA synthesis stimulated by tumor promoters. Carcinogenesis 1989;10:73-78. [PubMed: 2463115]

51. Braun L, Mead JE, Panzica M, Mikumo R, Bell GI, Fausto N. Transforming growth factor beta mRNA increases during liver regeneration: a possible paracrine mechanism of growth regulation. Proc Natl Acad Sci USA 1988;85:1539-1543. [PubMed: 3422749]

52. Carr BI, Hayashi I, Branum EL, Moses HL. Inhibition of DNA synthesis in rat hepatocytes by plateletderived Type B transforming growth factor. Cancer Res 1986;46:2330-2334. [PubMed: 3008986]

53. Nakamura T, Arakaki R, Ichihara A. Interleukin-1B is a potent growth inhibitor of adult rat hepatocytes in primary culture. Exp Cell Res 1988;179:488-497. [PubMed: 3263926] 


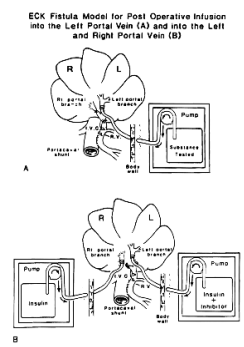

Fig. 1.

Eck fistula model for postoperative infusion into the (A) left portal vein and into the (B) left and right portal vein. 


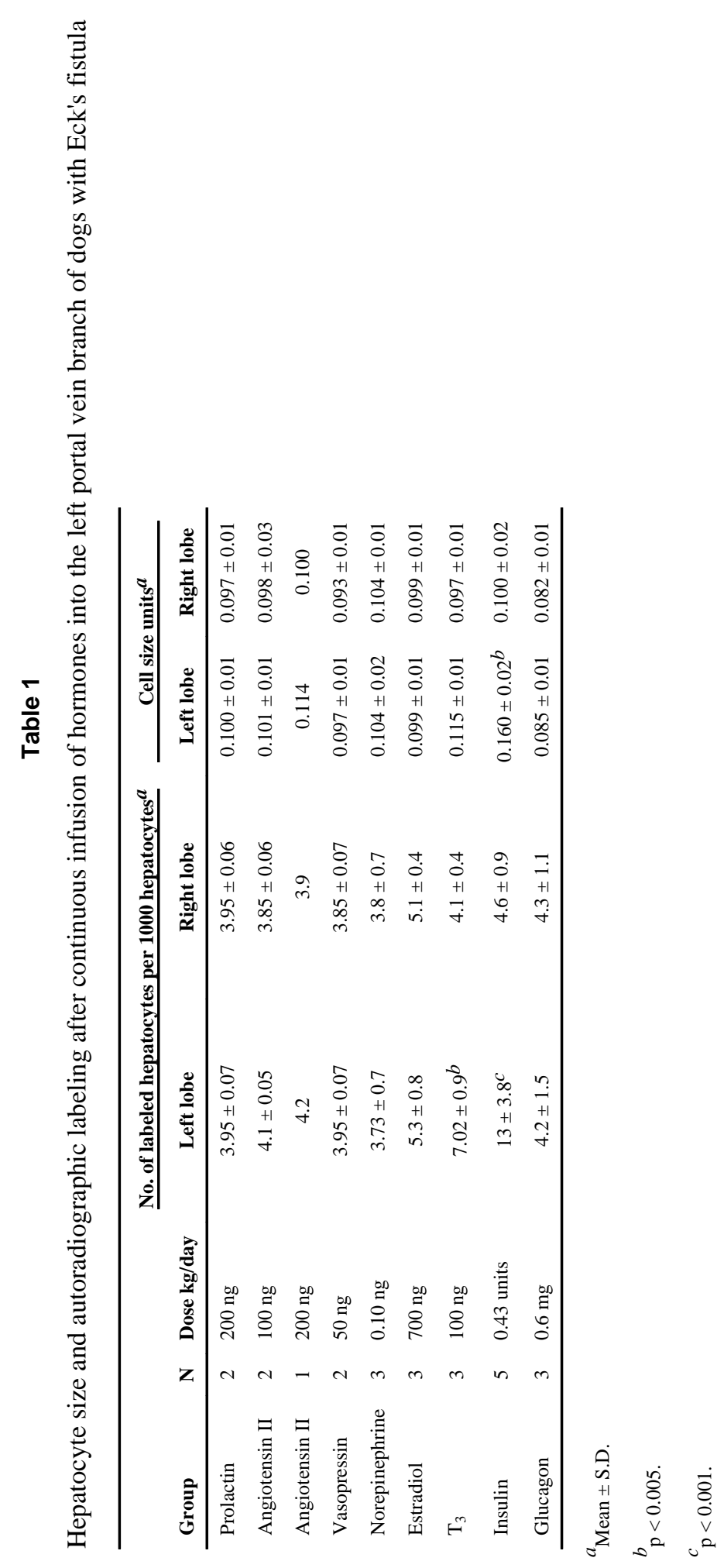

Hepatology. Author manuscript; available in PMC 2010 November 9. 


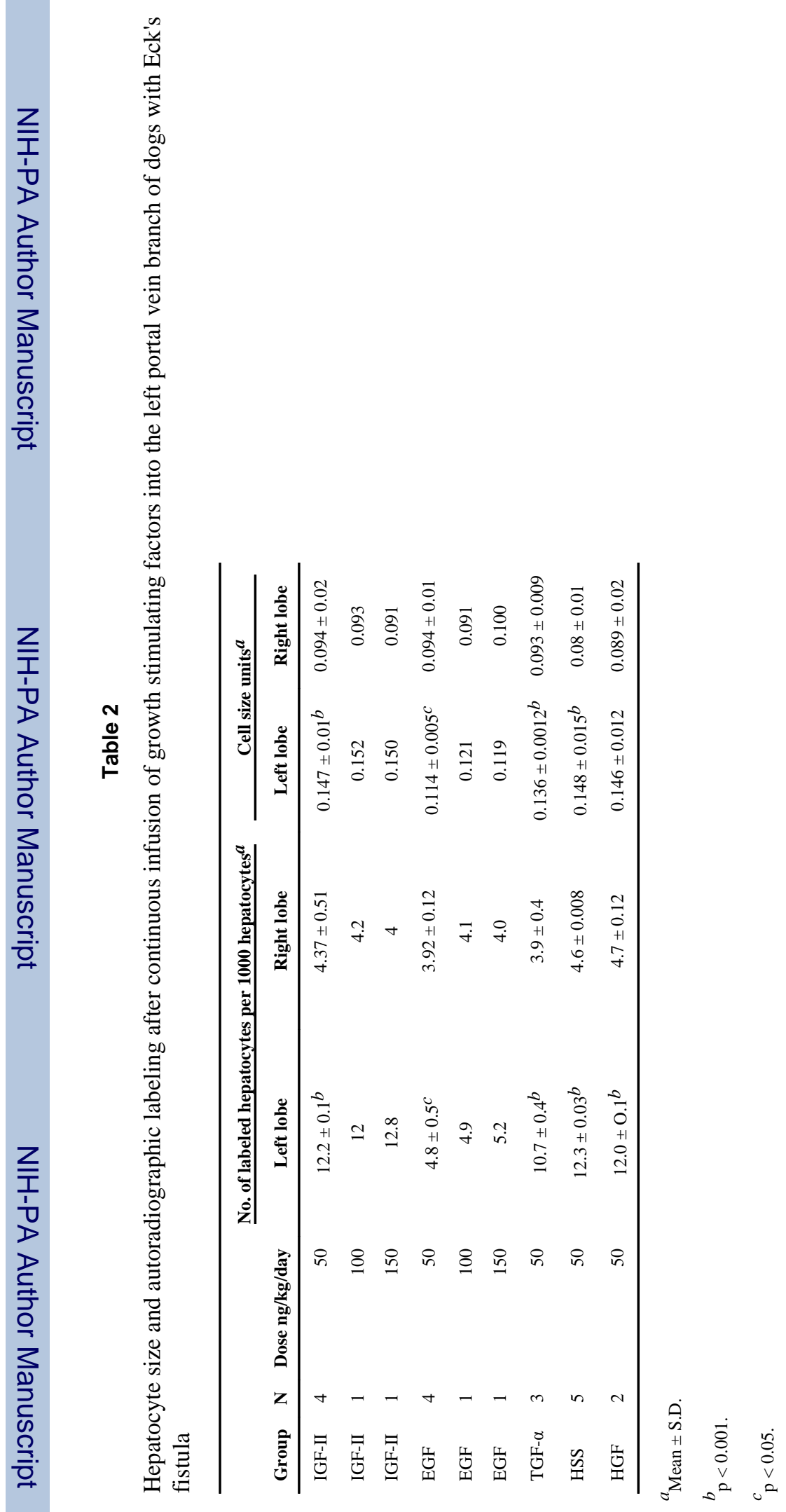




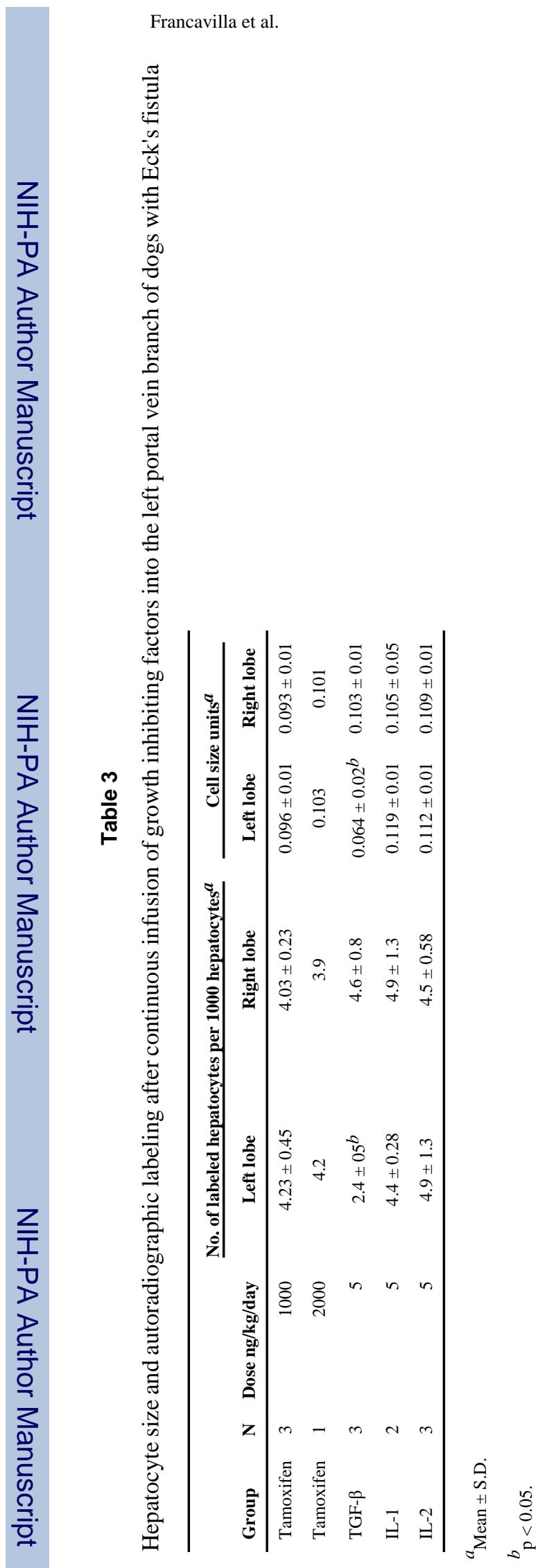

Hepatology. Author manuscript; available in PMC 2010 November 9. 


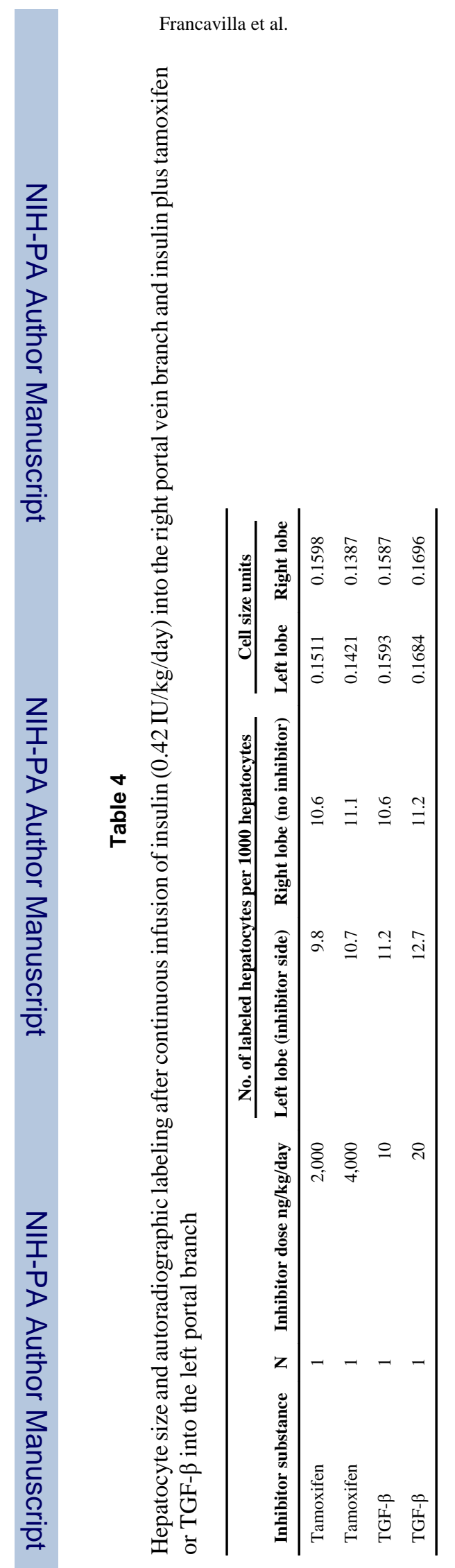

Hepatology. Author manuscript; available in PMC 2010 November 9. 